\title{
Custom-made transcriptional biosensors for metabolic engineering
}

DOI:

10.1016/j.copbio.2019.02.016

\section{Document Version}

Accepted author manuscript

Link to publication record in Manchester Research Explorer

\section{Citation for published version (APA):}

Koch, M., Pandi, A., Borkowski, O., Cardoso Batista, A., \& Faulon, J. L. (2019). Custom-made transcriptional biosensors for metabolic engineering. Current Opinion in Biotechnology, 59, 78-84.

https://doi.org/10.1016/j.copbio.2019.02.016

\section{Published in:}

Current Opinion in Biotechnology

\section{Citing this paper}

Please note that where the full-text provided on Manchester Research Explorer is the Author Accepted Manuscript or Proof version this may differ from the final Published version. If citing, it is advised that you check and use the publisher's definitive version.

\section{General rights}

Copyright and moral rights for the publications made accessible in the Research Explorer are retained by the authors and/or other copyright owners and it is a condition of accessing publications that users recognise and abide by the legal requirements associated with these rights.

\section{Takedown policy}

If you believe that this document breaches copyright please refer to the University of Manchester's Takedown Procedures [http://man.ac.uk/04Y6Bo] or contact uml.scholarlycommunications@manchester.ac.uk providing relevant details, so we can investigate your claim.

\section{OPEN ACCESS}




\title{
Custom-Made Transcriptional Biosensors for Metabolic Engineering
}

\author{
Mathilde Koch ${ }^{1,},{ }^{*}$ Amir Pandi ${ }^{1}{ }^{,}$, Olivier Borkowski ${ }^{2}$, Angelo Cardoso Batista ${ }^{1}$, Jean-Loup Faulon ${ }^{1,2,3} \dagger$ \\ ${ }^{1}$ Micalis Institute, INRA, AgroParisTech, Université Paris-Saclay, Jouy-en-Josas, France \\ 2 Génomique Métabolique, Genoscope, Institut François Jacob, CEA, CNRS, Univ Evry, \\ Université Paris-Saclay, 91057 Evry, France \\ ${ }^{3}$ SYNBIOCHEM Center, School of Chemistry, University of Manchester, Manchester, UK
}

*Equal contributions

†To whom correspondence should be addressed: jean-loup.faulon@inra.fr

Transcriptional biosensors allow screening, selection or dynamic regulation of metabolic pathways, and are therefore an enabling technology for faster prototyping of metabolic engineering and sustainable chemistry. Recent advances have been made, allowing for routine use of heterologous transcription factors, and new strategies such as chimeric protein design allow engineers to tap into the reservoir of metabolite-binding proteins. However, extending the sensing scope of biosensors is only the first step, and computational models can help in fine-tuning properties of biosensors for custom-made behavior.

Moreover, metabolic engineering is bound to benefit from advances in cell-free expression systems, either for faster prototyping of biosensors or for whole-pathway optimization, making it both a means and an end in biosensor design.

\section{Highlights}

- Successful examples of transcriptional biosensor implementations are presented

- Various engineering strategies extend the space of detectable chemicals

- Novel strategies exist to transform metabolite-responding proteins into biosensors

- Mathematical models of varying complexity can help tune biosensor properties

- Biosensors using or designed for cell-free systems are presented

\section{Introduction}

Metabolic engineering allows the production of value-added compounds from renewable sources, therefore making it a key discipline for a greener and more sustainable chemistry. As the domain of synthetic biology has matured, numerous techniques have been developed and applied in metabolic engineering, allowing for cheaper and faster DNA synthesis, sequencing and assembly. It is nowadays faster to design and build constructs than to characterize them as testing often involves expensive mass spectrometry analyses. This has led to an increased interest in biosensors, which can allow fast and real-time screening, selection or dynamic regulation engineering of metabolic pathways. Cells harboring fluorescent proteins as the reporter of the biosensor allow screening of a huge number of variants, both for experimental growth conditions or genetic constructs (enzymes, RBS, promoters). Moreover, dynamic regulation can be used to monitor intermediates, final products or quorum molecules, allowing for optimal pathway balancing and resource 
consumption.

The advantages of using biosensors in metabolic engineering have been extensively reviewed before [1-3] and will not be detailed further. Moreover, a wide array of techniques now exists to develop biosensors, from FRET [4] to riboswitches [5,6]: the interested reader is referred to those two excellent reviews that cover the strengths and limitations of the above-mentioned technologies $[7 \cdot, 8 \cdot \bullet]$. In this review, we will focus on transcriptional biosensors in three different aspects. First, we will review techniques for discovery and engineering of transcriptional biosensors for new compounds, second, we will present how computer-assisted modeling can facilitate the tuning of biosensors for custom-made behavior, and third we will review the advances and advantages of using cell-free systems for biosensor characterization and metabolic engineering.

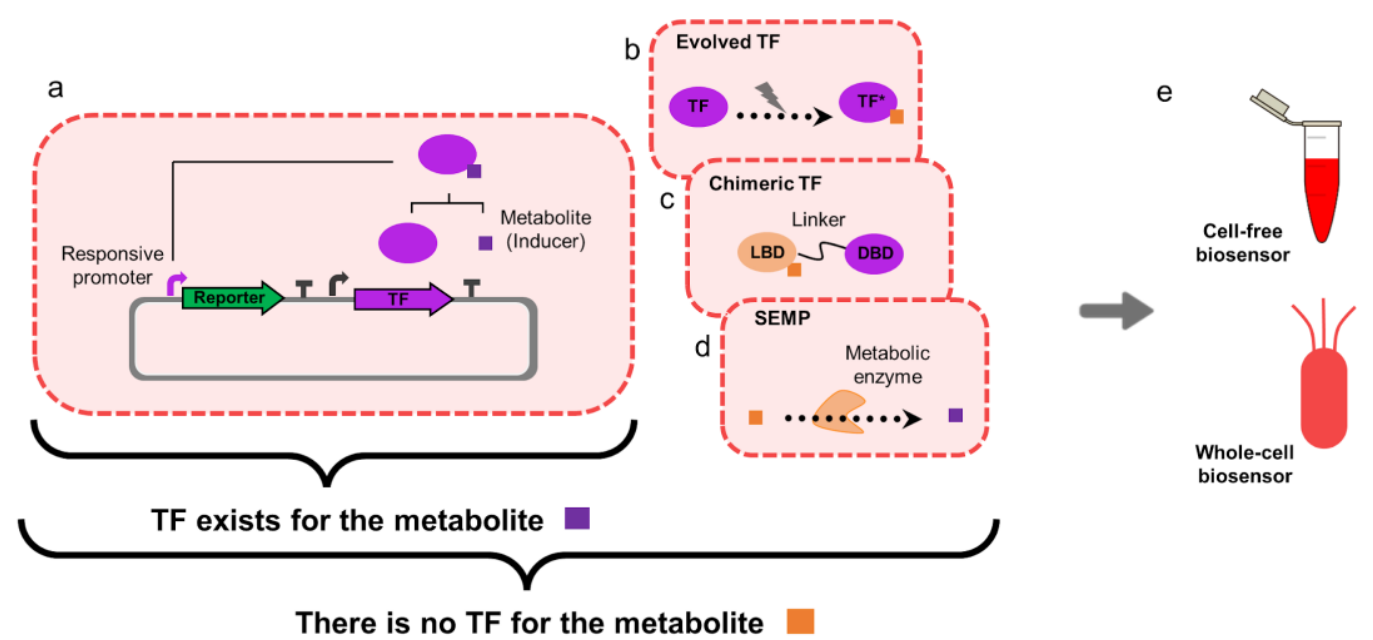

Figure 1. Different strategies to develop a TF based biosensor for a given metabolite. There is either an existing TF for a metabolite (a) or it could be engineered using evolved TF (b), chimeric protein (c), or a metabolic pathway (SEMP) (d). A designed biosensor could be implemented in whole-cell or cell-free system (e). Abbreviations: TF: Transcription Factor, LDB: Ligand Binding Domain, DBD: DNA Binding Domain, SEMP: Sensing-Enabling Metabolic Pathways.

\section{Designing a transcriptional biosensor to detect a compound of interest}

\section{Engineering allosteric transcription factors}

The first step to engineer a biosensor, whether homologous or heterologous, is to identify the transcription factor (TF) and promoters that respond to it. Strategies involving transcriptional micro-arrays and identification of the up- or down-regulated genes in response to the ligand of interest provide first leads. These approaches can suffer from important limitations for metabolic engineering use: the identified genes can be either indirectly regulated by the ligand of interest, or very unspecific. This strategy has been successfully applied for 1-butanol detection [9]. Another strategy for identification of potential TF-promoter pair comes from Zhang et al.[10••] who identified pairs that could detect lactam 
derivatives: they used a chemo-informatics approach to reveal operons listed in BRENDA (Braunschweig Enzyme Database) [11] that detected similar chemicals, and identified the gene likely coding the transcription factor. We recently published [12•] a dataset of detectable metabolites (Figure 1.a). This dataset, includes a manually curated list of experimentally validated detectable metabolites and information from databases of regulation, which contain known or putative detectable metabolites. Other strategies for mining parts have been discussed in a previous review [13].

\begin{tabular}{|c|c|c|c|c|c|}
\hline Compound & $\begin{array}{l}\text { Original } \\
\text { organism }\end{array}$ & $\begin{array}{l}\text { Impleme } \\
\text { ntation } \\
\text { organis } \\
\mathrm{m}\end{array}$ & $\begin{array}{l}\text { Design } \\
\text { strateg } \\
y\end{array}$ & $\begin{array}{l}\text { Biosen } \\
\text { sor } \\
\text { applicat } \\
\text { ion }\end{array}$ & $\begin{array}{l}\text { Referen } \\
\text { ce }\end{array}$ \\
\hline Itaconic acid & $\begin{array}{l}\text { Yersinia } \\
\text { pseudotuber } \\
\text { culosis }\end{array}$ & $\begin{array}{l}\text { Escheric } \\
\text { hia coli }\end{array}$ & $\begin{array}{l}\text { Identifie } \\
d \text { TF } \\
\text { and } \\
\text { promote } \\
\text { r from } \\
\text { cataboli } \\
\text { sm } \\
\text { pathway } \\
\text { s }\end{array}$ & $\begin{array}{l}\text { Used for } \\
\text { enzyme } \\
\text { improve } \\
\text { ment in } \\
\text { pathway } \\
\text { prototyp } \\
\text { ing }\end{array}$ & [14] \\
\hline Vanillin & $\begin{array}{l}\text { Escherichia } \\
\text { coli }\end{array}$ & $\begin{array}{l}\text { Escheric } \\
\text { hia coli }\end{array}$ & $\begin{array}{l}\text { Natural } \\
E . \text { coli } \\
\text { regulato } \\
r \text { tuned } \\
\text { with } \\
\text { mathem } \\
\text { atical } \\
\text { modelin } \\
g\end{array}$ & $\begin{array}{l}\text { Used for } \\
\text { library } \\
\text { screenin } \\
\mathrm{g}\end{array}$ & [15] \\
\hline $\begin{array}{l}\text { Syringaldehy } \\
\text { de }\end{array}$ & $\begin{array}{l}\text { Escherichia } \\
\text { coli }\end{array}$ & $\begin{array}{l}\text { Escheric } \\
\text { hia coli }\end{array}$ & $\begin{array}{l}\text { Natural } \\
\text { E. coli } \\
\text { regulato } \\
\text { r tuned } \\
\text { with } \\
\text { mathem } \\
\text { atical } \\
\text { modelin } \\
\mathrm{g}\end{array}$ & $\begin{array}{l}\text { Used for } \\
\text { library } \\
\text { screenin } \\
\mathrm{g}\end{array}$ & [15] \\
\hline
\end{tabular}




\begin{tabular}{|c|c|c|c|c|c|}
\hline Muconic acid & $\begin{array}{l}\text { Acinetobact } \\
\text { er sp. ADP1 }\end{array}$ & $\begin{array}{l}\text { Sacchar } \\
\text { omyces } \\
\text { cerevisia } \\
e\end{array}$ & $\begin{array}{l}\text { Identifie } \\
\text { d from a } \\
\text { previous } \\
\text { publicati } \\
\text { on }\end{array}$ & $\begin{array}{l}\text { Used for } \\
\text { selectio } \\
\mathrm{n} \text { of } \\
\text { high } \\
\text { produci } \\
\text { ng } \\
\text { strains }\end{array}$ & [16] \\
\hline Pinocembrin & $\begin{array}{l}\text { Herbaspirillu } \\
\text { m } \\
\text { seropedicae }\end{array}$ & $\begin{array}{l}\text { Escheric } \\
\text { hia coli }\end{array}$ & $\begin{array}{l}\text { Tuned } \\
\text { with the } \\
\text { help of a } \\
\text { mathem } \\
\text { atical } \\
\text { model }\end{array}$ & $\begin{array}{l}\text { Can be } \\
\text { used for } \\
\text { metaboli } \\
\text { c } \\
\text { enginee } \\
\text { ring }\end{array}$ & [17] \\
\hline Pamamycin & $\begin{array}{l}\text { Streptomyce } \\
\text { s alboniger }\end{array}$ & $\begin{array}{l}\text { Streptom } \\
\text { yces } \\
\text { alboniger }\end{array}$ & $\begin{array}{l}\text { Improve } \\
\text { d from } \\
\text { native } \\
\text { genetic } \\
\text { element } \\
\text { s }\end{array}$ & $\begin{array}{l}\text { Can be } \\
\text { used for } \\
\text { metaboli } \\
\text { c } \\
\text { enginee } \\
\text { ring }\end{array}$ & [18] \\
\hline $\begin{array}{l}\text { p-coumaric } \\
\text { acid }\end{array}$ & $\begin{array}{l}\text { Bacillus } \\
\text { subtilis }\end{array}$ & $\begin{array}{l}\text { Escheric } \\
\text { hia coli }\end{array}$ & $\begin{array}{l}\text { Identifie } \\
d \text { from } \\
\text { literatur } \\
\text { e and } \\
\text { library } \\
\text { design } \\
\text { of RBS } \\
\text { to tune } \\
\text { the } \\
\text { repress } \\
\text { or } \\
\text { properti } \\
\text { es }\end{array}$ & $\begin{array}{l}\text { Used for } \\
\text { screenin } \\
\mathrm{g} \mathrm{a} \\
\text { produce } \\
\mathrm{r} \text { strain } \\
\text { in } \\
\text { microflui } \\
\text { dic } \\
\text { droplets }\end{array}$ & [19] \\
\hline $\begin{array}{l}\text { Formaldehyd } \\
\text { e }\end{array}$ & $\begin{array}{l}\text { Escherichia } \\
\text { coli }\end{array}$ & $\begin{array}{l}\text { Escheric } \\
\text { hia coli }\end{array}$ & $\begin{array}{l}\text { Optimiz } \\
\text { ed from } \\
\text { native } \\
\text { regulato } \\
\text { ry } \\
\text { element } \\
\text { s. }\end{array}$ & $\begin{array}{l}\text { Used to } \\
\text { identify } \\
\text { promisin } \\
\mathrm{g} \\
\text { enzyme } \\
\text { s for } \\
\text { methan } \\
\text { ol } \\
\text { assimila } \\
\text { tion. }\end{array}$ & [20] \\
\hline
\end{tabular}




\begin{tabular}{|c|c|c|c|c|c|}
\hline $\begin{array}{l}\mathrm{N}- \\
\text { acetylneura } \\
\text { minic acid }\end{array}$ & $\begin{array}{l}\text { Escherichia } \\
\text { coli }\end{array}$ & $\begin{array}{l}\text { Escheric } \\
\text { hia coli }\end{array}$ & $\begin{array}{l}\text { Modulari } \\
\text { zation of } \\
\text { the } \\
\text { native } \\
\text { biosensi } \\
\text { ng } \\
\text { system }\end{array}$ & $\begin{array}{l}\text { Used for } \\
\text { screenin } \\
\mathrm{g} \text { high- } \\
\text { produci } \\
\text { ng } \\
\text { strains }\end{array}$ & [21] \\
\hline Putrescine & $\begin{array}{l}\text { Escherichia } \\
\text { coli }\end{array}$ & $\begin{array}{l}\text { Escheric } \\
\text { hia coli }\end{array}$ & $\begin{array}{l}\text { Modulari } \\
\text { zation of } \\
\text { the } \\
\text { native } \\
\text { biosensi } \\
\text { ng } \\
\text { system }\end{array}$ & $\begin{array}{l}\text { Used for } \\
\text { screenin } \\
\text { g high- } \\
\text { produci } \\
\text { ng } \\
\text { strains }\end{array}$ & [22] \\
\hline $\begin{array}{l}\text { L- } \\
\text { phenylalanin } \\
\text { e }\end{array}$ & $\begin{array}{l}\text { Escherichia } \\
\text { coli }\end{array}$ & $\begin{array}{l}\text { Escheric } \\
\text { hia coli }\end{array}$ & $\begin{array}{l}\text { Modulari } \\
\text { zation of } \\
\text { the } \\
\text { native } \\
\text { biosensi } \\
\text { ng } \\
\text { system }\end{array}$ & $\begin{array}{l}\text { Used for } \\
\text { screenin } \\
\text { g high- } \\
\text { produci } \\
\text { ng } \\
\text { strains }\end{array}$ & [23] \\
\hline Shikimic acid & $\begin{array}{l}\text { Corynebact } \\
\text { erium } \\
\text { glutamicum }\end{array}$ & $\begin{array}{l}\text { Coryneb } \\
\text { acterium } \\
\text { glutamic } \\
\text { um }\end{array}$ & $\begin{array}{l}\text { Using } \\
\text { the } \\
\text { promote } \\
r \text { from } \\
\text { native } \\
\text { genetic } \\
\text { element } \\
s \text {, } \\
\text { consider } \\
\text { ing the } \\
\text { transcrip } \\
\text { tion } \\
\text { factor to } \\
\text { be } \\
\text { naturally } \\
\text { express } \\
\text { ed }\end{array}$ & $\begin{array}{l}\text { Used for } \\
\text { screenin } \\
\text { g high- } \\
\text { produci } \\
\text { ng } \\
\text { strains }\end{array}$ & [24] \\
\hline Cellobiose & $\begin{array}{l}\text { Thermobifid } \\
\text { a fusca }\end{array}$ & $\begin{array}{l}\text { Escheric } \\
\text { hia coli }\end{array}$ & $\begin{array}{l}\text { Identifie } \\
d \text { from } \\
\text { literatur } \\
\text { e and } \\
\text { express } \\
\text { ed in } E \text {. }\end{array}$ & $\begin{array}{l}\text { Used to } \\
\text { identify } \\
\text { promisin } \\
\mathrm{g} \\
\text { cellulas } \\
\text { es }\end{array}$ & [25] \\
\hline
\end{tabular}




\begin{tabular}{|c|c|c|c|c|c|}
\hline & & & coli & & \\
\hline Naringenin & $\begin{array}{l}\text { Herbaspirillu } \\
\text { m } \\
\text { seropedicae }\end{array}$ & $\begin{array}{l}\text { Escheric } \\
\text { hia coli }\end{array}$ & $\begin{array}{l}\text { Identifie } \\
d \text { from } \\
\text { literatur } \\
\text { e, } \\
\text { modulari } \\
\text { zed and } \\
\text { express } \\
\text { ed in } E \text {. } \\
\text { coli }\end{array}$ & $\begin{array}{l}\text { Can be } \\
\text { used for } \\
\text { metaboli } \\
\text { c } \\
\text { enginee } \\
\text { ring }\end{array}$ & [26] \\
\hline Naringenin & $\begin{array}{l}\text { Acinetobact } \\
\text { er sp. ADP1 }\end{array}$ & $\begin{array}{l}\text { Sacchar } \\
\text { omyces } \\
\text { cerevisia } \\
e\end{array}$ & $\begin{array}{l}\text { Identifie } \\
\text { d from } \\
\text { literatur } \\
\text { e, } \\
\text { modulari } \\
\text { zed and } \\
\text { express } \\
\text { ed in } E \text {. } \\
\text { coli }\end{array}$ & $\begin{array}{l}\text { Used for } \\
\text { pathway } \\
\text { prototyp } \\
\text { ing - } \\
\text { screenin } \\
\text { g }\end{array}$ & [27] \\
\hline $\begin{array}{l}\text { Various } \\
\text { aromatic } \\
\text { blocks }\end{array}$ & $\begin{array}{l}\text { Sphingobiu } \\
m \text { sp. SYK-6 }\end{array}$ & $\begin{array}{l}\text { Escheric } \\
\text { hia coli }\end{array}$ & $\begin{array}{l}\text { Identifie } \\
\text { d from } \\
\text { literatur } \\
\text { e, } \\
\text { modulari } \\
\text { zed and } \\
\text { express } \\
\text { ed in } E \text {. } \\
\text { coli }\end{array}$ & $\begin{array}{l}\text { Used to } \\
\text { screen } \\
\text { for lignin } \\
\text { degradi } \\
\text { ng } \\
\text { enzyme } \\
\text { s }\end{array}$ & [28] \\
\hline $\begin{array}{l}\text { Various } \\
\text { macrolides }\end{array}$ & $\begin{array}{l}\text { MphR, } \\
\text { isolated } \\
\text { from } \\
\text { wastewater } \\
\text { treatment } \\
\text { plant }\end{array}$ & $\begin{array}{l}\text { Escheric } \\
\text { hia coli }\end{array}$ & $\begin{array}{l}\text { Directed } \\
\text { evolutio } \\
\mathrm{n} \text { and } \\
\text { random } \\
\text { mutage } \\
\text { nesis to } \\
\text { improve } \\
\text { selectivit } \\
\text { y }\end{array}$ & $\begin{array}{l}\text { Can be } \\
\text { used for } \\
\text { metaboli } \\
\text { c } \\
\text { enginee } \\
\text { ring }\end{array}$ & [29] \\
\hline
\end{tabular}

Table 1: Successful homologous and heterologous biosensor design based identified on transcription factor/promoter pairs. 
Once a potential TF/promoter pair is identified, the bioengineering workflow involves modifying the promoter, RBS and binding sites to improve selectivity, dynamic, operational range, fold change and leakiness. A number of successful biosensors have been developed in recent years, including heterologous TF despite the challenges faced to adapt the transcriptional machinery. This technology is becoming increasingly mature, as shown by the numerous examples in Table 1. In addition, engineering of specific biosensors for MalonylCoA is reviewed by Johnson et al. [30], while Ambri [31] describes in details an implementation of bacterial TF in yeast. Voigt's group recently published an $E$. coli strain containing twelve genomically integrated small molecule sensors, using a directed evolution strategy. It has been developed as a synthetic biology tool but the presented methods are applicable to metabolic engineering [32].

However, the above-mentioned strategies are only applicable if a natural transcription factorbiosensor pair exists for a given compound. We will now review strategies to extend the chemical scope of transcriptional biosensors.

\section{Extending the chemical space for biosensors}

A strategy to extend the chemical scope is to start from a known transcription factor and apply rounds of protein engineering to change its specificity (Figure 1.b). For example, to design a biosensor for lactulose, Lacl was altered using saturation mutagenesis, with rounds of selection to ensure specificity to lactulose [33]. Taylor et al. [34••] used computer-assisted protein design, followed by saturation or random mutagenesis to modify Lacl to sense either fucose, gentiobiose, lactitol or sucralose. The promiscuous MphR transcription factor has been modified with a similar strategy to change its selectivity towards various macrolides [29]. Despite their successes, these examples still rely on well-known transcription factors and labor-intensive mutagenesis or computationally assisted protein design to change the specificity of a transcription factor to, still, a chemically similar molecule.

Several groups have tried radical approaches, fusing DNA binding domains (DBD) to determine ligand binding domains in different ways (Figure 1.c). This strategy has been successfully applied to maltose [35] and benzoate [36] by testing various linkers and DBD systematically. Another strategy, also applied to maltose, was to randomly insert the DBD into the metabolite binding protein, using transposon insertion reaction, to select constructs presenting biosensor-like behavior [37•]. In a recent study [38•], the authors use a ligand dependent stabilization strategy, fusing Lacl (respectively MphR) to the Zif268 DBD and RNA polymerase $\omega$-subunit transcription-activating domain. Those constructs are quickly degraded unless the ligand is present. The authors managed to engineer biosensors responding to IPTG and D-glucose with satisfying dose-response (respectively erythromycin with a modest response). However, to underline the difficulty of this approach, they report that in two structurally similar periplasmic binding proteins, a similar mutation did not confer ligand dependent stabilization. Another similar approach was developed recently, it uses both ligand dependent stabilization and protein dimerization: two ligand binding domains (that can homodimerize, but bind different ligands) are fused respectively to the activation domain and the DBD. Upon ligand binding, the two proteins are stable and can homodimerize, resulting in biosensing. This system allows for better range tuning and possible orthogonal biosensing of different ligands [39].

Other known metabolite responsive proteins are two-component systems, which have also been used as biosensors. By fusing the transmembrane sensing domain of another species 
detecting methanol with the cytoplasmic phosphorylation domain of E. coli, binding of methanol activates a phosphorylation cascade enabling biosensing [40]. In an elegant study, transmembrane and cytosolic receptors for caffeine were built by fusing single-domain antibodies to monomeric DBDs [41]. Different DBDs were used, proving the scalability of the method. These two platforms should allow bioengineers to tap into the vast reservoir of twocomponent systems and antibodies to design new sensors.

A radically different approach to engineer the sensing scope of bacteria was coined SensingEnabling Metabolic Pathways (SEMP) (Figure 1.d). The principle of this method is to metabolically convert an undetectable ligand into an already detectable one. This method makes the most of existing biosensors as well as of the impressive accumulated knowledge on metabolic reactions. It has been successfully applied in a metabolic engineering project to produce 3-hydroxypropionate [42], and its modularity was shown by Libis et al. [43]. A webserver is now available to design SEMP for compounds of interest [44].

\section{Computer-assisted fine-tuning of biosensor properties}

While the scientific community agrees that biosensors need to be fine-tuned for selectivity, sensitivity and dynamic range, tuning strategies are usually based on labor-intensive and costly rounds of selection and mutagenesis. Controlling those properties is especially interesting for metabolic engineering as the specifications of a biosensor needed during various stages of the process will change, from detecting micromolar amounts before pathway optimization to $\mathrm{g} / \mathrm{L}$ titers in later development stages. Therefore, after engineering a biosensor with new specificity, its properties also need to be fine-tuned to match the metabolic engineer's needs.

A detailed mechanistic model of the ArsR arsenic biosensor was developed by Berset et al. [45], which recapitulates the sensor behavior under various circuit configurations, different ArsR alleles, promoter strengths, and presence or absence of arsenic efflux in the bioreporters. This model was then used to predict a circuit variant with steeper response at low arsenite concentrations. A thermodynamical model was developed in a recent study [46••], which was used to tune the dynamic range of ligand-inducible promoters (mainly AraC and LasR), using binding energies calculated for different promoter sequences. Both studies proved that with sufficiently detailed models, tailoring biosensor properties for custom-made behavior can be achieved. Another interesting study based on the Lac system and involving extensive phenomenological modeling sought to find theoretical constraints for biosensor design, notably a maximum achievable dynamic range and exposing tunable parameters for orthogonal control of dynamic range and response threshold [47]. As impressive as these studies are, they are based on well-characterized and known systems and such modeling cannot be applied easily to a new biosensor.

However, a simpler formalism (Michaelis-Menten) for mathematical modeling was used to tune a biosensor used for selection of lignin transforming enzymes, giving insights on parameters influencing sensitivity, such as TF concentrations or copy number [15]. The role of plasmid copy number on sensitivity and fold-change of a pinocembrin and naringenin biosensor was investigated through a mathematical modeling [17], using the common Hill 
framework, allowing for better understanding of the biosensor behavior and suggestions for further tuning of properties according to desired outputs. Landry et al. [48] used mathematical modeling with Hill formalism to tune the detection range of a two-component system. They successfully applied it to improve their detection threshold up to two orders of magnitude. These later studies showed that simple mathematical models can help to understand and tune specific properties of a biosensor, even in less known systems.

Computer-assisted design does not always yield the expected results, as current models are often more explicative a posteriori than predictive a priori. Therefore, we believe investing the time needed to develop reliable models for a library of constructs can only be worthwhile in the long run for designing biosensors, as formalized knowledge is more easily translatable to other situations.

\section{Custom-made biosensors' new application domain: cell-free metabolic engineering}

Despite the advances presented in this review, biosensor design still necessitates rounds of trial and error. This limitation can be significantly sped up by using cell-free systems (Figure 1.e). Moreover, cell-free systems, are poised to become a key characterization tool in the metabolic engineering workflow before in vivo implementation. Cell-free systems lead to quicker responses, simpler cloning and larger combinatorial libraries screening, without requiring transformation steps. These systems can also be an appropriate platform for production because of lower noise and toxicity and absence of resource competition between pathway and cell growth. To date, cell-free systems have been applied to implement pathways for violacein [49], 4-BDO [50], polyhydroxyalkanoates bioplastics [51], mevalonate [52], $n$-butanol [53] and raspberry ketone [54], using either transcriptiontranslation (TX-TL) systems, overexpressed enzymes in the crude extract or purified enzymes. Advantages and possibilities of cell-free systems for metabolic engineering has been reviewed elsewhere [55], and a methods chapter for pathway prototyping in cell-free systems has recently been published [56].

Cell-free biosensors for various applications have been reviewed elsewhere [57] and we will focus on strategies applicable to metabolic engineering. In a recent study, a vanillin biosensor was developed in cell-free systems [58••]. The authors first used computational protein design and then rapid cell-free prototyping to develop a biosensor for this toxic effector, which was subsequently used in dynamic control loops in vivo to alleviate toxicity.

Another use of cell-free systems for biosensor engineering is discussed by Halleran et al [59]: to develop complex consortia for pathway distribution among cell populations, metabolic engineers need reliable quorum sensing systems. This study characterized crosstalk between cell-free system and in vivo and discovered significant correlation between cellfree and in vivo measurements, validating the use of cell-free systems as a successful and fast characterization testbed. Recently, we have proposed a method to optimize the response of TF-based cell free biosensors. We also proved that SEMP are modularly implementable in cell-free systems, and exhibit high sensitivity, fast response times and broad dynamic range [60]. 
For this review, we implemented our in vivo-characterized pinocembrin biosensor [17] in a cell-free system (Figure 2.a). The cell-free biosensor exhibited a linear correlation between input concentration and fluorescence intensity as well as a wider dynamic and operational range (Figure 2.b) compared to its in vivo counterpart [17]. These tools could be used for real-time screening and speed up the design-build-test-learn workflow for metabolic engineering.
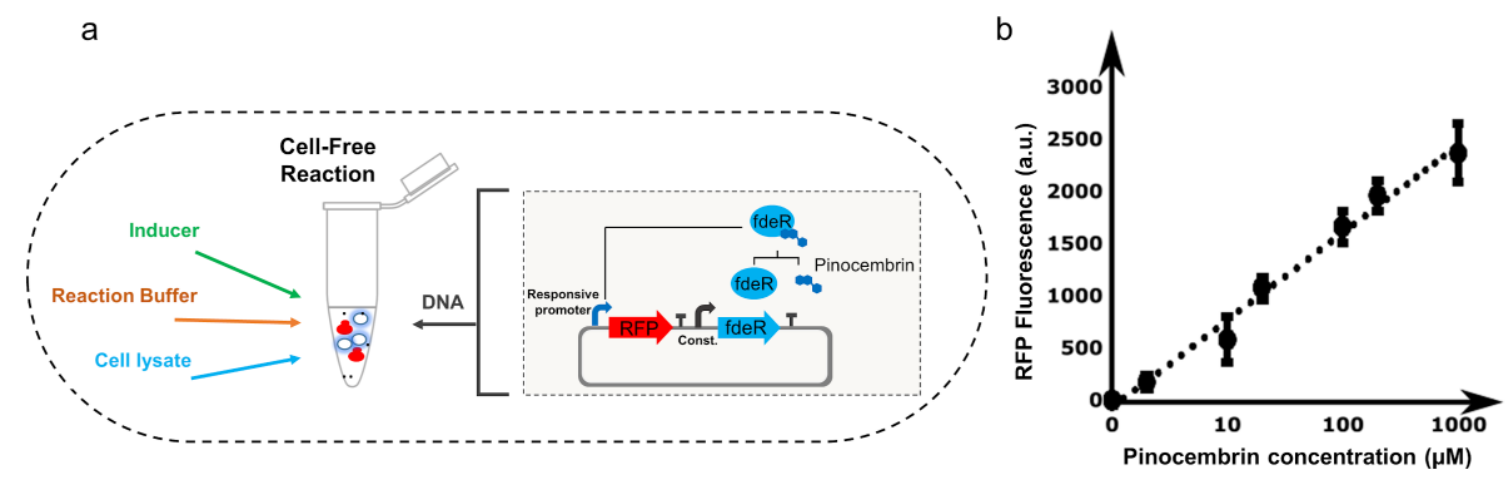

Figure 2. Pinocembrin cell-free biosensor. Cell-free reaction consists of TX-TL cell lysate, reaction buffer and DNA plus inducer for the biosensor (a). (b) The graph shows a dose response RFP fluorescence after 9 hours incubation in a plate reader at $30^{\circ} \mathrm{C} 40 \mathrm{nM}$ of biosensor plasmid is added with $0,1,2,10,20,100,200$ or 1000 $\mu \mathrm{M}$ of pinocembrin in $10.5 \mu \mathrm{l}$ of cell-free reaction. RFP fluorescence points and error bars are the mean and standard deviation of three measurements.

Cell-free systems provide fascinating new opportunities for metabolic engineering, both for faster biosensor development, notably for toxic products, but also for prototyping whole pathways. Cell-free based metabolic engineering can benefit from all advantages of biosensor-based screening or dynamic regulation engineering, as does traditional metabolic engineering.

\section{Conclusion}

Thanks to extensive efforts by the research community, it has never been easier to develop transcriptional biosensors for new compounds, either from existing TF or engineering strategies. We believe the next frontier in custom-made biosensor design resides in efficient fine-tuning of properties, which is greatly advanced by modeling efforts. Moreover, metabolic engineering might be entering a new phase, with cell-free systems enabling faster prototyping of biosensors and even whole pathways. The current advances in biosensors for high-throughput screening will truly allow the field to move from the Design-Build-Test cycle to the Design-Build-Test-Learn cycle.

\section{References and recommended reading}

Papers of particular interest, published within the period of review, have been highlighted as:

- of special interest 
•• of outstanding interest

\section{Acknowledgments}

JLF acknowledges support from BBSRC/EPSRC (grant number BB/M017702/1) and from the ANR SINAPUV grant number ANR-17-CE07-0046. MK is supported by DGA (French Ministry of Defense) and Ecole Polytechnique and AP is supported by INRA (National Institute for Agricultural Research) and idEx interdisciplinary scholarship from Paris-Saclay. OB is supported by Genopole "Allocation Recherche 2017" and CRI Paris "Short-term Fellows".

\section{References}

1. Liu D, Evans T, Zhang F: Applications and advances of metabolite biosensors for metabolic engineering. Metab Eng 2015, 31:35-43.

2. de Frias UA, Pereira GKB, Guazzaroni M-E, Silva-Rocha R: Boosting secondary metabolite production and discovery through the engineering of novel microbial biosensors. Biomed Res Int 2018, 2018:7021826.

3. Liu Y, Liu Y, Wang M: Design, optimization and application of small molecule biosensor in metabolic engineering. Front Microbiol 2017, 8:2012.

4. Ameen S, Ahmad M, Mohsin M, Qureshi MI, Ibrahim MM, Abdin MZ, Ahmad A: Designing, construction and characterization of genetically encoded FRET-based nanosensor for real time monitoring of lysine flux in living cells. J Nanobiotechnology 2016, 14:49.

5. Xiu Y, Jang S, Jones JA, Zill NA, Linhardt RJ, Yuan Q, Jung GY, Koffas MAG: Naringeninresponsive riboswitch-based fluorescent biosensor module for Escherichia coli co-cultures. Biotechnol Bioeng 2017, 114:2235-2244.

6. Ruscito A, McConnell EM, Koudrina A, Velu R, Mattice C, Hunt V, McKeague M, DeRosa MC: In vitro selection and characterization of DNA aptamers to a small molecule target. Curr Protoc Chem Biol 2017, 9:233-268.

7.-_Carpenter AC, Paulsen IT, Williams TC: Blueprints for biosensors: design, limitations, and applications. Genes 2018, 9.

A recent full review on all types of biosensors with detailed classifications and examples.

8.•-_Rogers JK, Taylor ND, Church GM: Biosensor-based engineering of biosynthetic pathways. Curr Opin Biotechnol 2016, 42:84-91.

A review on application of biosensors for metabolic engineering with a focus on screening and selection.

9. Shi S, Choi YW, Zhao H, Tan MH, Ang EL: Discovery and engineering of a 1-butanol biosensor in Saccharomyces cerevisiae. Bioresour Technol 2017, 245:1343-1351.

10.•-Zhang J, Barajas JF, Burdu M, Ruegg TL, Dias B, Keasling JD: Development of a transcription 
factor-based lactam biosensor. ACS Synth Biol 2017, 6:439-445.

The authors present a method for identifying transcription factor/ promoter pairs based on chemical similarity search in enzymatic databases.

11. Jeske L, Placzek S, Schomburg I, Chang A, Schomburg D: BRENDA in 2019: a European ELIXIR core data resource. Nucleic Acids Res 2019, 47:D542-D549.

12. -Koch M, Pandi A, Delépine B, Faulon J-L: A dataset of small molecules triggering transcriptional and translational cellular responses. Data Brief 2018, 17:1374-1378.

A dataset of detectable metabolites, consisting of manually extracted examples of biosensors in synthetic biology as well as gathered data from related databases.

13. Libis V, Delépine B, Faulon J-L: Sensing new chemicals with bacterial transcription factors. Curr Opin Microbiol 2016, 33:105-112.

14. Hanko EKR, Minton NP, Malys N: A Transcription factor-based biosensor for detection of itaconic acid. ACS Synth Biol 2018, 7:1436-1446.

15. Ho JCH, Pawar SV, Hallam SJ, Yadav VG: An improved whole-cell biosensor for the discovery of lignin-transforming enzymes in functional metagenomic screens. ACS Synth Biol 2018, 7:392398.

16. Snoek T, Romero-Suarez D, Zhang J, Skjoedt ML, Sudarsan S, Jensen MK, Keasling JD: An orthogonal and pH-tunable sensor-selector for muconic acid biosynthesis in yeast. 2017, doi:10.1101/229922.

17. Trabelsi H, Koch M, Faulon J-L: Building a minimal and generalizable model of transcription factor-based biosensors: Showcasing flavonoids. Biotechnol Bioeng 2018, doi:10.1002/bit.26726.

18. Rebets Y, Schmelz S, Gromyko O, Tistechok S, Petzke L, Scrima A, Luzhetskyy A: Design, development and application of whole-cell based antibiotic-specific biosensor. Metab Eng 2018, 47:263-270.

19. Siedler S, Khatri NK, Zsohár A, Kjærbølling I, Vogt M, Hammar P, Nielsen CF, Marienhagen J, Sommer MOA, Joensson HN: Development of a bacterial biosensor for rapid screening of yeast p-coumaric acid production. ACS Synth Biol 2017, 6:1860-1869.

20. Woolston BM, Roth T, Kohale I, Liu DR, Stephanopoulos G: Development of a formaldehyde biosensor with application to synthetic methylotrophy. Biotechnol Bioeng 2018, 115:206-215.

21. Peters G, De Paepe B, De Wannemaeker L, Duchi D, Maertens J, Lammertyn J, De Mey M: Development of $\mathrm{N}$-acetylneuraminic acid responsive biosensors based on the transcriptional regulator NanR. Biotechnol Bioeng 2018, 115:1855-1865.

22. Chen X-F, Xia X-X, Lee SY, Qian Z-G: Engineering tunable biosensors for monitoring putrescine in Escherichia coli. Biotechnol Bioeng 2018, 115:1014-1027.

23. Liu Y, Zhuang Y, Ding D, Xu Y, Sun J, Zhang D: Biosensor-based evolution and elucidation of a biosynthetic pathway in Escherichia coli. ACS Synth Biol 2017, 6:837-848.

24. Liu C, Zhang B, Liu Y-M, Yang K-Q, Liu S-J: New intracellular shikimic acid biosensor for 
monitoring shikimate synthesis in Corynebacterium glutamicum. ACS Synth Biol 2018, 7:591601.

25. Kwon KK, Yeom S-J, Lee D-H, Jeong KJ, Lee S-G: Development of a novel cellulase biosensor that detects crystalline cellulose hydrolysis using a transcriptional regulator. Biochem Biophys Res Commun 2018, 495:1328-1334.

26. De Paepe B, Maertens J, Vanholme B, De Mey M: Modularization and response curve engineering of a naringenin-responsive transcriptional biosensor. ACS Synth Biol 2018, 7:1303-1314.

27. Skjoedt ML, Snoek T, Kildegaard KR, Arsovska D, Eichenberger M, Goedecke TJ, Rajkumar AS, Zhang J, Kristensen $\mathrm{M}$, Lehka BJ, et al.: Engineering prokaryotic transcriptional activators as metabolite biosensors in yeast. Nat Chem Biol 2016, 12:951-958.

28. Machado LFM, Dixon N: Development and substrate specificity screening of an in vivo biosensor for the detection of biomass derived aromatic chemical building blocks. Chem Commun 2016, 52:11402-11405.

29. Kasey CM, Zerrad M, Li Y, Cropp TA, Williams GJ: Development of transcription factor-based designer macrolide biosensors for metabolic engineering and synthetic biology. ACS Synth Biol 2018, 7:227-239.

30. Johnson AO, Gonzalez-Villanueva M, Wong L, Steinbüchel A, Tee KL, Xu P, Wong TS: Design and application of genetically-encoded malonyl-CoA biosensors for metabolic engineering of microbial cell factories. Metab Eng 2017, 44:253-264.

31. Ambri F, Snoek T, Skjoedt ML, Jensen MK, Keasling JD: Design, engineering, and characterization of prokaryotic ligand-binding transcriptional activators as biosensors in yeast. Methods Mol Biol 2018, 1671:269-290.

32. Meyer AJ, Segall-Shapiro TH, Voigt CA: Marionette: E. coli containing $\mathbf{1 2}$ highly-optimized small molecule sensors. 2018, doi:10.1101/285866.

33. Wu J, Jiang $\mathrm{P}$, Chen $\mathrm{W}$, Xiong $\mathrm{D}$, Huang L, Jia J, Chen $\mathrm{Y}$, Jin J-M, Tang S-Y: Design and application of a lactulose biosensor. Sci Rep 2017, 7:45994.

34..-Taylor ND, Garruss AS, Moretti R, Chan S, Arbing MA, Cascio D, Rogers JK, Isaacs FJ, Kosuri S, Baker $\mathrm{D}$, et al.: Engineering an allosteric transcription factor to respond to new ligands. Nat Methods 2016, 13:177-183.

The authors present a method for computer-assisted mutagenesis to change a transcription factor's specificity.

35. Younger AKD, Dalvie NC, Rottinghaus AG, Leonard JN: Engineering modular biosensors to confer metabolite-responsive regulation of transcription. ACS Synth Biol 2017, 6:311-325.

36. Juárez JF, Lecube-Azpeitia B, Brown SL, Johnston CD, Church GM: Biosensor libraries harness large classes of binding domains for construction of allosteric transcriptional regulators. Nat Commun 2018, 9:3101.

37.-_Younger AKD, Su PY, Shepard AJ, Udani SV, Cybulski TR, Tyo KEJ, Leonard JN: Development of novel metabolite-responsive transcription factors via transposon-mediated protein fusion. Protein Eng Des Sel 2018, 31:55-63. 
The authors use a chimeric protein strategy by inserting a ligand binding domain into a DNA binding protein to create repressors.

38. Brandsen BM, Mattheisen JM, Noel T, Fields S: A biosensor strategy for $\boldsymbol{E}$. coli based on liganddependent stabilization. ACS Synth Biol 2018, doi:10.1021/acssynbio.8b00052.

The authors fuse DNA binding, ligand binding and transcription recruiting domains to generate activator, by achieving ligand-dependent stabilization.

39. Jester B, Tinberg CE, Rich MS, Baker D, Fields S: Engineered biosensors from dimeric ligandbinding domains. ACS Synth Biol 2018, doi:10.1021/acssynbio.8b00242.

40. Selvamani V, Ganesh I, Maruthamuthu MK, Eom GT, Hong SH: Engineering chimeric twocomponent system into Escherichia coli from Paracoccus denitrificans to sense methanol. Biotechnol Bioprocess Eng 2017, 22:225-230.

41. Chang H-J, Mayonove P, Zavala A, De Visch A, Minard P, Cohen-Gonsaud M, Bonnet J: A modular receptor platform To expand the sensing repertoire of bacteria. ACS Synth Biol 2018, 7:166-175.

42. Rogers JK, Church GM: Genetically encoded sensors enable real-time observation of metabolite production. Proc Natl Acad Sci U S A 2016, 113:2388-2393.

43. Libis V, Delépine B, Faulon J-L: Expanding biosensing abilities through computer-aided design of metabolic pathways. ACS Synth Biol 2016, 5:1076-1085.

44. Delépine B, Libis V, Carbonell P, Faulon J-L: SensiPath: computer-aided design of sensingenabling metabolic pathways. Nucleic Acids Res 2016, 44:W226-31.

45. Berset $\mathrm{Y}$, Merulla $\mathrm{D}$, Joublin A, Hatzimanikatis V, van der Meer JR: Mechanistic modeling of genetic circuits for ArsR arsenic regulation. ACS Synth Biol 2017, 6:862-874.

46.•-Chen Y, Ho JML, Shis DL, Gupta C, Long J, Wagner DS, Ott W, Josić K, Bennett MR: Tuning the dynamic range of bacterial promoters regulated by ligand-inducible transcription factors. Nat Commun 2018, 9:64.

The authors use a thermodynamical model to guide the optimization of their biosensor properties.

47. Mannan AA, Liu D, Zhang F, Oyarzún DA: Fundamental design Principles for transcriptionfactor-based metabolite biosensors. ACS Synth Biol 2017, 6:1851-1859.

48. Landry BP, Palanki R, Dyulgyarov N, Hartsough LA, Tabor JJ: Phosphatase activity tunes twocomponent system sensor detection threshold. Nat Commun 2018, 9:1433.

49. Nguyen PHB, Wu Y, Guo S, Murray RM: Design space exploration of the violacein pathway in Escherichia coli based transcription translation cell-free system (TX-TL). 2015, doi:10.1101/027656.

50. Wu YY, Culler S, Khandurina J, Van Dien S, Murray RM: Prototyping 1,4-butanediol (BDO) biosynthesis pathway in a cell-free transcription-translation (TX-TL) system. 2015, doi:10.1101/017814.

51. Kelwick R, Ricci L, Chee SM, Bell D, Webb AJ, Freemont PS: Cell-free prototyping strategies for 
enhancing the sustainable production of polyhydroxyalkanoates bioplastics. 2017, doi:10.1101/225144.

52. Dudley QM, Anderson KC, Jewett MC: Cell-free mixing of Escherichia coli crude extracts to prototype and rationally engineer high-titer mevalonate synthesis. ACS Synth Biol 2016, 5:1578-1588.

53. Karim AS, Heggestad JT, Crowe SA, Jewett MC: Controlling cell-free metabolism through physiochemical perturbations. Metab Eng 2018, 45:86-94.

54. Moore SJ, Tosi T, Hleba YB, Bell D, Polizzi K, Freemont P: A cell-free synthetic biochemistry platform for raspberry ketone production. 2017, doi:10.1101/202341.

55. Jiang L, Zhao J, Lian J, Xu Z: Cell-free protein synthesis enabled rapid prototyping for metabolic engineering and synthetic biology. Synth Syst Biotechnol 2018, 3:90-96.

56. Karim AS, Jewett MC: Cell-free synthetic biology for pathway prototyping. Methods Enzymol 2018, 608:31-57.

57. Soltani M, Davis BR, Ford H, Nelson JAD, Bundy BC: Reengineering cell-free protein synthesis as a biosensor: Biosensing with transcription, translation, and protein-folding. Biochem Eng J 2018, 138:165-171.

58.•-_de los Santos ELC, Meyerowitz JT, Mayo SL, Murray RM: Engineering transcriptional regulator effector specificity using computational design and In vitro rapid prototyping: developing a vanillin sensor. ACS Synth Biol 2016, 5:287-295.

The authors use computational design and cell-free prototyping to develop a biosensor for a toxic compound.

59. Halleran A, Murray RM: Cell-free and in vivo characterization of Lux, Las, and Rpa quorum activation systems in E. coli. 2017, doi:10.1101/159988.

60. Voyvodic PL, Pandi A, Koch M, Faulon J-L, Bonnet J: Plug-and-play metabolic transducers expand the chemical detection space of cell-free biosensors. 2018, doi:10.1101/397315. 